\title{
LESSONS IN MEDICAL POLITICS: THOMAS WAKLEY AND THE IRISH MEDICAL CHARITIES, 1827-39
}

\author{
by \\ RONALD D. CASSELL *
}

Thomas Wakley (1795-1862), the founding editor of the Lancet, has an assured place in the history of medical reform in England. A friend of William Cobbett, the radical activist who helped him establish the Lancet in 1823, Wakley fought vested interests through his journal as well as in the House of Commons, where he served as the Member for Finsbury from 1835 to 1852. A nice assessment of his temperament and politics appears in the Dictionary of National Biography, which describes him as "an ardent reformer with strong sympathies with the chartists, an advocate of the repeal of the Irish union, a strenuous opponent of the corn laws, and an enemy to lawyers." 1

Wakley's use of the Lancet as a forum from which to attack the entrenched medical élites was one of the crucial ingredients in the developing medical reform movement. Throughout the British Isles, the early decades of the nineteenth century were marked by a profound redefinition of the roles, identities, and status of the differing categories of practitioners within the medical profession. Generally speaking, the old tripartite division into physicians, surgeons, and apothecaries was breaking down to be replaced by the modern distinction between consultants and general practitioners. ${ }^{2}$ In Wakley's day this translated into a struggle between the surgeon-apothecaries, who made up the rank and file of the provincial practitioners, and the well-connected physicians and surgeons who dominated the lucrative hospital teaching positions and the councils of the Royal Colleges in London, Edinburgh, and Dublin. A Victorian practitioner, describing the circumstances of the 1820 s when he was a young man, remembers them as follows. "No man, whatever his talents or acquirements, had the least chance of

* Ronald D. Cassell, Ph.D., Dept. of History, University of North Carolina at Greensboro, Greensboro NC 27412-5001, USA.

A preliminary version of this paper was delivered at the Carolinas Symposium for British Studies, East Tennessee State University, October 1985.

${ }^{1}$ See also S. S. Sprigge, The life and times of Thomas Wakley, London, Longmans, Green \& Co., 1897, pp. 73-7.

2 The best recent studies of this process are Ivan Waddington, The medical profession in the Industrial Revolution, Dublin, Gill \& Macmillan, 1984, and Irvine Loudon, Medical care and the general practitioner, Oxford, Clarendon Press, 1986. 


\section{Thomas Wakley and the Irish medical charities}

obtaining a Hospital appointment unless he were connected with the staff by family or other ties, or had a large command of capital."3 The assumption of such privileged superiority, and the fees and influence that went with it, infuriated a man of Wakley's temperament and politics and led him to mount an aggressive challenge.

Wakley's role in the heroic phase of the medical reform movement is familiar fare. For example, in the celebrated case (1828) of Bransby Blake Cooper, a surgeon at Guy's and nephew to the more famous and accomplished Astley Paston Cooper, Wakley not only described in extensive detail the former's prolonged and clumsy operation for removal of stone, which resulted in the death of the patient, but asserted that he "was a surgeon because he was a nephew". Bransby Cooper sued and got the verdict but Wakley used the trial to discredit him and virtually establish his charge of malpractice. ${ }^{4}$

In the early days of the Lancet, monopoly, especially that of the London College of Surgeons, was the major focus of Wakley's wrath. The Council of that institution was, in the $1820 \mathrm{~s}$, a closed body which replenished its numbers largely from among friends and relatives. Wakley challenged that oligarchic arrangement in 1824 . The Court of Examiners of the College had issued a by-law requiring students to attend the lectures of the hospital surgeons. At that time many students studied with surgeons not attached to hospitals and this ruling was designed to end that practice. Wakley saw it as preventing many able surgeons from teaching. He instituted an inquiry which revealed that the Court of Examiners was composed entirely of hospital surgeons. Wakley's response was to organize the rank-and-file members of the profession and demand the democratization of the College constitution, thus initiating a conflict between himself and the College hierarchy that lasted for decades and led to the famous incident in 1831 when he was carried from the College theatre by the police. ${ }^{5}$

Wakley's involvement in the medical politics of Ireland grew initially out of his attack upon monopoly. Rapidly gaining a large readership in Ireland, the Lancet frequently carried articles and notices concerning Irish medical affairs. Between 1824 and 1836 Wakley maintained a correspondent in Dublin who contributed regular pieces under the pen-name "Erinensis". Now thought to be Dr Peter Hennis Green, a graduate of Trinity College and for some years an assistant and Demonstrator to Professor James Macartney there, Erinensis produced a series of articles on the Irish medical colleges and hospitals. ${ }^{6}$ Consistent with the editorial policy of his employer, Erinensis probed for nepotism, monopoly, corruption, and inefficiency of every kind. His particular target was the Irish College of Surgeons, which he portrayed as sharing many of the same defects as its London counterpart.

While thus hotly engaged with both the London and Dublin colleges, the Lancet began to receive letters complaining about the monopoly of Irish county infirmary

\footnotetext{
${ }^{3}$ James F. Clarke, Autobiographical recollections of the medical profession, London, J. \& A. Churchill, 1874 , p. 11.

4 The standard account is in Sprigge, op. cit., note 1 above, p. 151. A much more detailed and complex treatment is found in Clarke, op. cit., note 3 above, pp. 29-71.

${ }^{5}$ Sprigge, op. cit., note 1 above, pp. 216-17.

${ }^{6}$ Martin Fallon, ed., The sketches of Erinensis. Selections of Irish medical satire, 1824-36, London, Skilton Shaw, 1979, pp. 8-10.
} 


\section{Ronald D. Cassell}

appointments enjoyed by the licentiates of the Royal College of Surgeons Ireland. ${ }^{7}$ The county infirmaries were small regional hospitals, considered, along with the Dublin hospitals, as the finest medical institutions in the country. In the 1820 s there were 41 of them and in many parts of Ireland they constituted the only source of professional surgical care. Correspondingly, in a period of overabundance of medical men, infirmary appointments with their guaranteed salary and promise of practice among the gentry, were much in demand. ${ }^{8}$ But many Irish practitioners, otherwise impeccably credentialed with degrees from London and Edinburgh, lacked the licence of the Irish College of Surgeons. ${ }^{9}$ Nor was this certificate easy to obtain.

At this time the Irish college considered its requirements the most rigorous in the British Isles. It alone demanded a classical medical education for its licentiates as well as comprehensive work in surgery. Neither London nor Edinburgh demanded as much medicine, nor were their examinations public (that is, open to the members of the colleges) or thought to be as difficult. ${ }^{10}$ However, the major hurdle for any student aspiring to the Irish licence lay in its price and the time required to qualify for the examination. Under its original charter (1784) the College required five years' residency and fees totalling some 200 guineas. $^{11}$

Fully prepared by his fierce quarrel with the London College of Surgeons to oppose monopolies anywhere, Wakley ignored the Dublin college's claims to academic and professional excellence and championed the cause of the unlicensed practitioners. In a series of editorials beginning in December 1827, Wakley argued for the liberalization of the College's regulations along lines that would open the examinations to candidates other than those apprenticed to the existing members of the College. By thus abandoning the residency requirement, graduates of other schools of surgery in the United Kingdom and students of non-College surgeons would be given an opportunity to qualify in Ireland. ${ }^{12}$

Wakley's campaign contributed to the reform of certain aspects of the College's requirements. Though determined to maintain the rigour of its academic programme and its hold on the infirmary positions, the College obtained a new charter in 1828 and in the following year adopted revised requirements. Students were to produce either a certificate showing they had attended certain sets of lectures stipulated by the College and been present at hospital practice, or, if they had not been resident at the College of Surgeons, evidence of six years of study at a hospital or other school of

\footnotetext{
${ }^{7}$ For a contemporary discussion of the monopoly issue and the requirements of the Irish College of Surgeons see the Lancet, 1825-26, i: 698-701; and 1826-27, i: 791-4.

${ }^{8}$ The best-informed account of the infirmaries and their problems in the late 1820 s is Denis Phelan, $A$ statistical inquiry into the present state of the medical charities of Ireland ..., Dublin, Hodges \& Smith, College Green, 1835, pp. 20-71.

9 Ibid., pp. 56-7.

10 J. D. H. Widdess, The Royal College of Surgeons in Ireland and its Medical School, 1784-1966, 2nd ed., Edinburgh and London, E. \& S. Livingstone, 1967, pp. 47, 79. John Fleetwood, A history of medicine in Ireland, Dublin, Brown \& Nolan, 1951, p. 92. See also the Lancet, 1837-38, i: 906-7. In his calmer moments even Wakley could admit the virtues of the Irish programme in surgical education. See the conclusion to his editorial in the Lancet, 1827-28, i: 564 , and his note to correspondents, ibid., 1837-38, ii: 352.

11 Widdess, op. cit., note 10 above, p. 11 .

12 Lancet, 1827-28, i: 465-7, 498-500, 529-32, 562-4.
} 


\section{Thomas Wakley and the Irish medical charities}

medicine or surgery. Specific academic requirements were toughened still further. ${ }^{13}$ More significantly, perhaps, the controversy stimulated consultations among representatives of the three great colleges of surgery, resulting eventually (1838) in the adoption of common standards for their licentiates. ${ }^{14}$ But Wakley's hostility to the Irish college remained unabated, largely because of the continued agitation over its monopoly of the medical officer posts at the county infirmaries. Indeed, in subsequent years his attitude appears to have hardened. In language typical of the style Wakley thought appropriate to medical-political debate, he described the Dublin college as,

a mere selfish faction, contemptible alike in point of numbers and talent, who would still, as they have ever done, sacrifice every consideration and every interest, to maintain ... their monopoly which has been so long the ready and mischievous instrument of their avarice and malignity . . ${ }^{15}$ [The College was] . . . a trades' union perverted [differing] from other trades' unions inasmuch as the proceedings of its members are directed against the great majority of the profession it was founded to protect: ... like a palace cemented with blood, ... [it] is upheld by the sufferings and unmitigated diseases of a nation. ${ }^{16}$

By 1837, however, the infirmaries issue had been moved into the background, submerged in the larger controversy developing over the question of reform of the whole of the Irish medical charities. And Wakley and the Lancet were prepared to play a central role in the new debate. Before we can consider that role, however, it will be helpful to say a little more about Irish medical charity.

Medical charities was the term used to denote a body of more or less specialized medical-care institutions which had grown up in Ireland since the middle of the eighteenth century. By the mid-1830s, they consisted of the 41 county infirmaries, already described, as well as some 70 fever hospitals, nearly 600 dispensaries, and 10 lunatic asylums. ${ }^{17}$ These institutions differed from similar institutions in the rest of the United Kingdom in a number of respects. In particular, they had been established by public statute, which defined their administrative and financial arrangements, and were financed in part by government subsidies. Similar facilities in England and Scotland were private charities, founded, administered, and financed by local, private benefactors and served by medical personnel who volunteered their time and skills. The classic examples are the English voluntary hospitals and infirmaries typical of the period and the public dispensaries, which often were attached to them and served as out-patient clinics. ${ }^{18}$ But, compared to Ireland, England was rich and could support

\footnotetext{
${ }^{13}$ Widdess, op. cit., note 10 above, p. 70.

${ }^{14}$ Ibid., p. 119. See also the speech of Henry Maunsell to the Irish College of Surgeons, 10 Nov. 1838. Reprinted in the Lancet, 1838-39, i: 317.

I5 Ibid., 1836-37, ii: 378 .

16 Ibid., 1837-38, i: 862-3.

${ }_{17}$ Report of the Poor Law Commission on the Medical Charities (Ireland), H. C. (1841), xi, 1-7.

${ }^{18}$ For English medical charity arrangements see John Woodward, To do the sick no harm, London, Routledge \& Kegan Paul, 1974, pp. 1-74; Brian Abel-Smith, The hospitals 1800-1948, Cambridge, Mass., Harvard University Press, 1964, pp. 1-100; Ruth Hodgkinson, The origins of the National Health Service, London, The Wellcome Historical Medical Library, 1967, pp. 185-249; and I. S. L. Loudon, 'The origins and growth of the dispensary movement in England', Bull. Hist. Med., 1981, 55: 322-42.
} 


\section{Ronald D. Cassell}

such a system by private charity. Moreover, she had a Poor Law that provided a form of medical care, funded through parish rates, for the most impoverished portion of the population. Ireland lacked both. Out of necessity, therefore, Irish medical charity had come to possess a governmental dimension absent from other parts of the United Kingdom.

In 1765 an act of the Irish Parliament permitted the establishment of an infirmary in every county except Dublin and Waterford, which already possessed hospitals. Governance and administration for each institution were vested in a corporation composed of a number of important figures from the gentry and clergy, who were made ex-officio members, and local contributors, who could obtain either an annual membership for three guineas or life membership for twenty. ${ }^{19}$ So constituted, such an institution would have resembled a voluntary hospital. But given the poverty of the Irish gentry, few infirmaries could have been expected to be funded. What made the Infirmary Act work were the additional incentives in the form of an annual grant from the Irish (after the Union in 1800 , the UK) treasury of $£ 100$ and county grants of (by the 1830s) nearly $£ 1,500$ a year for each institution. ${ }^{20}$ The coupling of state and local subsidies and private contributions proved to be a winning arrangement. Subsequently the other medical charities were established on similar grounds: a series of statutes in the early nineteenth century permitted the creation of governing bodies for the dispensaries and fever hospitals, composed of local subscribers, who then petitioned the Grand Juries (the county agencies responsible for judicial and revenue matters) for matching funds in proportions defined by the statutes pertaining at the time. ${ }^{21}$ By the late 1830 s, not counting the asylums which had come under different and more centralized governmental administration and financing, this combination of private and public funding had given Ireland something like a medical Poor Law, which treated perhaps a million patients annually at a cost of slightly more than $£ 140,000$. $^{22}$

Although large amounts of government money were expended, there was no right to relief granted to the poor in general, as was theoretically true of the English Poor Law. On the other hand, using Irish medical charity did not make the recipients legally paupers, with all the loss of status and rights that involved, as the use of the Poor Law medical services did in England. In practice the system worked much like the English voluntary hospitals and public dispensaries. Subscribers, life members, and medical officers had the exclusive right to distribute "tickets" to those persons among the "deserving poor" who applied to them for help. The dispensaries were the most common of the medical charities and operated basically as out-patient clinics dispensing medicines and advice. The fever hospitals were isolation centres for fever, smallpox, and other diseases thought to be contagious. The infirmaries provided surgical and medical care on an extended basis and were roughly equivalent to the English voluntary hospitals.

\footnotetext{
${ }^{19}$ Phelan, op. cit., note 8 above, pp. 114-15.

20 Ibid., pp. $20-1$.

${ }^{21}$ R. B. MacDowell, The Irish administration 1801-1914, London, Routledge \& Kegan Paul, 1964, pp. $166-7$.

22 P.L.C. Report, op. cit., note 17 above, pp. 1-26.
} 


\section{Thomas Wakley and the Irish medical charities}

Though a remarkable achievement given Ireland's limited resources, the medical charities system was in trouble by the 1830 s. The rapid growth of the Irish population in the early nineteenth century (from 5 million in 1801 to about 8.5 million in 1845) vastly increased the numbers in the lowest economic sectors traditionally dependent on the free service offered by the medical charities. Those institutions increased to meet the need, but as they did so the lack of clearly defined regulations and standards produced what came to be seen as unacceptable variations in the organizational arrangements as well as in the level and quality of services provided. Four Parliamentary committees, a Royal Commission, and a private study investigated the state of the Irish poor in general and of the medical charities in particular in the $1830 \mathrm{~s}$ and 1840s. Insofar as they defined and initiated the debate on the state of the Irish medical charities, the most important of these investigations was that by Denis Phelan (1785-1871), an apothecary-surgeon who served for a time as a dispensary medical officer in Tipperary, and the Poor Inquiry Commission chaired by the Archbishop of Dublin, Richard Whately. ${ }^{23}$ Both inquiries revealed inefficiency, irrationality, and corruption and were sufficiently alarming to arouse considerable public debate and virtually guarantee some form of legislative action. In addition, the proposals each put forward were far ahead of their time, calling for, among other things, the creation of an extensive national health system, financed out of public revenue, to provide a larger proportion of free medicines and treatment for the sick poor than the existing medical charities could manage. ${ }^{24}$ However, the development of an overall policy for dealing with the Irish poor could not be confined to Ireland alone. Inevitably it became linked to English efforts along the same lines. And English ideas were very different from those of Archbishop Whately or Dr Phelan.

The new English Poor Law, with its Boards of Guardians, workhouses, lesseligibility principle, and its central administrative board in London, which was being put into place in 1834, was intended to limit and toughen poor relief in order to drive malingerers off the rates and back to work and so reduce the dangerous spiral of poor law expenditures. This basic financial consideration was blended with the zeal for rational and centralized reform which lay at the core of the Utilitarian movement. Thus the austere spirit of the New Poor Law was in complete opposition to the comparatively generous, almost modern programme proposed by the Whately Commission.

Political considerations in the mid-1830s militated against the adoption of the Whately Commission proposals. The second Melbourne administration, a weak coalition of Whig, Radical, and Irish interests, with a small majority in the Commons and facing a substantial Tory majority in the Lords, was not in a position to insist upon a more expensive and theoretically different kind of Poor Law programme for Ireland, even if it had believed in it. ${ }^{25}$ Thus Ireland inevitably received the kind of

\footnotetext{
${ }^{23}$ Phelan, op. cit., note 8 above; and Report of the Commissioners Inquiring into the Condition of the Poor in Ireland, Appendix B, H.C., 1835, xxxii, 8-14.

${ }^{24}$ Phelan, op. cit., note 8 above, pp. 166-71; Report, op. cit., note 23 above, pp. 12-14.

${ }^{25}$ Melbourne considered Whately to be muddle-headed and refused to take either him or his report seriously. "It was impossible to be with him ten minutes without knowing that not only can he do no business, but that no business can be done in his presence", he observed to Lord John Russell. John Prest, Lord John Russell, Columbia, University of South Carolina Press, 1972, p. 113.
} 


\section{Ronald D. Cassell}

Poor Law England was in the process of getting. In 1837 the English government moved legislation through the Commons designed to extend the English Poor Law to Ireland. A separate measure placed the medical charities on the poor rate, provided them with a medical inspectorate, and brought them under the overall administrative supervision of the Poor Law authority. ${ }^{26}$

This was a serious measure which had every prospect of passing. It had the support of the Irish administration, of Irish MPs known for their interest in medical charities reform, and of many members of the Irish medical community. For the latter it had many attractions. It raised the medical charities to a national scale, provided for their rational distribution, improved their funding, and created a professional inspectorate, thereby establishing the principle that, as one medical reformer put it, "the power of regulating the public medical charities of a country shall be entrusted to members of the medical profession, responsible to the public and to the government."27 The London Medical and Surgical Journal, edited by Michael Ryan, always an interested observer of the Irish medical scene, came out in strong support for the new measure. ${ }^{28}$ The one critical note was sounded by the Lancet.

Wakley despised and feared the Poor Law Commission. Its policy toward its medical personnel owed much to the ideas of the Secretary to the Commission, Edwin Chadwick, who had little use for medical science or its practitioners. He thought medicine a "sham" and considered doctors were only "pretending to alleviate disease which if they had the will they had not the skill to prevent". ${ }^{29}$ Consequently, the Poor Law Commission had confined its role in the new system to workhouse medical officers, encouraged the Guardians to hire persons licensed to practise as "medical men", leaving it to the Guardians to define for themselves what this meant, and absolutely refused to consider appointing a medical commissioner to the central Poor Law authority, arguing that one might as well have an architectural commissioner or a baker or trades commissioner. ${ }^{30}$

The hostility and suspicion bred in the medical profession by this policy governed Wakley's reaction to the Medical Charities Bill of 1837. In spite of its many virtues, which he acknowledged, the whole bill was eternally compromised in his eyes by its eighth clause, which stipulated that the Poor Law Commission should "exercise a general superintendence" over all of the medical charities. ${ }^{31}$ In an editorial of 3 June 1837 Wakley began his campaign warning that the effect would be, "if ever such an odious measure shall be enacted into law, to insult and enthrall the whole body of Irish practitioners, and ultimately, the whole medical fraternity of England and Scotland." $32 \mathrm{He}$ called for public meetings of the profession in London and throughout the kingdom at which medical men should make their feelings known to the government.

${ }^{26}$ A Bill for the Better Regulation of Hospitals, Dispensaries and other Medical Charities in Ireland, H.C., 1837, iii, 373-82.

${ }^{27}$ See the comments of Denis Phelan in the Lancet, 1836-37, ii: 412.

28 Lond. med. surg. J., 1836-37, 2: 715.

${ }^{29}$ S. E. Finer, The life and times of Sir Edwin Chadwick, London, Methuen, 1952, p. 158.

30 Ibid., pp. 157-8.

31 Bill for Regulation of Hospitals ..., H.C., 1837, iii, 375.

32 Lancet, 1836-37, ii: 381 . 
Wakley's attack triggered an immediate defence of the bill from two representatives of the Irish medical profession, Denis Phelan, the well-known critic of the existing medical charities system, and Morgan Nugent, a medical officer in Cork. Both men knew the problems of the Irish medical charities at first hand and were eager for reform. They argued that Wakley was mistaken in his view that the Poor Law Commission was being granted ultimate power over the medical charities. ${ }^{33}$ They stressed that the medical inspectors were to be appointed and removed by the Lord Lieutenant, not the Commission, and that the inspectors were fully empowered to sit as a board and make general regulations for the care of patients and general management of medical charities. They reminded Wakley that the bill set a precedent insofar as it gave control of the medical charities to the medical profession.

Wakley's response effectively silenced further support for the bill from the medical side. He excused Phelan and Nugent by suggesting that they had probably been deceived by the Commission itself, "for those grasping despots of Somerset-house are trying to contaminate, with their pestilential breath, the offices of every charitable medical institution in the empire." ${ }^{34}$ He went on to argue that they could not have read Clause 47 of the Irish Poor Law Bill, which stated clearly that the Commission would have the power to issue orders for the government of the medical charities and the officers thereof as the

Commissioners may deem necessary for the prevention of any conflict between the objects and purposes of this act. Aye, there is to be "no conflict"... In other words the system of tyranny, of oppression, of restriction, and of moderate diet and low salaries, [is] to be uniform. The profession and the people are not to have the opportunity of making any unfavourable comparisons. ${ }^{35}$

In the weeks that followed Wakley hammered away in his journal and in the House of Commons, where his position as the "medical member", as he liked to see himself, provided both a forum and a unique vantage point. He clearly gained ground yet the skilful handling of the measure by the Chief Secretary, Lord Morpeth, appeared to make its passage virtually certain. But then on 20 June 1837 the King, William IV, died and as the contemporary phrase so graphically put it, all pending bills fell to the ground.

The government did not bring forward their Medical Charities Bill in 1838. Their experience with the doctors in the previous session had not been encouraging and they appear to have thought that a less direct approach might yield more positive results. Thus they introduced an Irish Poor Law Bill, which dealt only obliquely with the medical charities, and lent their enthusiastic support to a medical charities bill which was put forward from another source. Technically it was private bill, the work of Fitzstephen French, the member for Roscommon, the co-author of the 1837 bill. $^{36}$ The Chancellor of the Exchequer, Spring Rice, a frequent champion of Irish reforms,

33 Ibid., pp. 411-12.

34 Ibid.

35 Ibid., p. 414.

${ }^{36}$ A Bill for the Better Regulation of Hospitals, Dispensaries and other Medical Charities in Ireland, H.C., 1837-38, iv, 611-12. 


\section{Ronald D. Cassell}

"rejoiced at the introduction of the bill . . . [and assured French] that the government were disposed to render him every assistance." 37 French's association with Morpeth in the previous year and the government's gushing endorsement suggest collusion. Whether true or not, it is certainly clear that greater care had been taken in drafting the 1838 measure.

At first glance, French's bill appears to meet the major criticisms levelled against its predecessor. It called for putting the medical charities on the Poor Rate and establishing a medical inspectorate, as had the 1837 bill. But administration was to be through an unpaid board consisting of senior members of the medical profession, thus eliminating the objectionable linkage with the Poor Law authority. And, unlike its predecessor, this measure had been drawn up with the advice and assistance of key members of the Dublin medical community. ${ }^{38}$ Having, he thought, squared the fiercest critics of his previous measure, French undoubtedly felt he had every chance for success. Of course, by so favouring the medical interest, he opened his bill up to lay oppositon, which was not long in coming. Various members were vehement in their objections to the principle of taxing the Irish people in order to obtain advantages for the medical men and in depriving the Grand Juries of their traditional role in supervising the funding and administration of the medical charities. ${ }^{39}$ But French must have anticipated such charges and have counted on the support of the government to overcome them. In the early phases of the bill's legislative progress, Morpeth remained a steady ally. ${ }^{40}$ What was to doom the measure were the attacks from within the medical community itself, which must have come as a nasty shock after all the careful preparations.

Wakley in particular was not appeased. In a series of editorials in the Lancet in the spring of 1838 he vigorously set forth his objections. He had little regard for unpaid boards:

... such officers cannot be trusted; their conduct is too well known from numerous, long, ruinous experiments ... A barber without sequins, converted into a governor of a Turkish province, may give a faint idea of an unpaid, unfed, Irish Commissioner, suddenly set at liberty among the charities of his country. No man is more likely to apply the vulgar proverb, "Charity begins at home."41

Next, Wakley turned to his second and most serious objection-the qualifications stipulated for medical officers to the medical charities. The officers were to be either physicians or surgeons with certificates from one of the degree-granting medical institutions in the UK. In addition, if they were surgeons they must have had five years of schooling, three years of hospital practice, plus proof of having been examined for two hours on anatomy, surgery, medicine, and midwifery. Physicians must demonstrate four years of schooling and two years of hospital practice. Wakley

${ }^{37}$ Hansard, 3rd ser., vol. 40 (1838), 831-2.

38 'Report Presented to the Royal College of Surgeons by Dr. Maunsell on the Medical Charities Bill of 1838', Royal Irish Academy, Tracts, Box 477, T.44.

39 Hansard, 3rd ser., vol. 42 (1838), 720.

40 Ibid., 721-2.

41 Lancet, 1837-38, i: 833. 


\section{Thomas Wakley and the Irish medical charities}

saw in these requirements the work of his recent enemies, the Irish College of Surgeons. He charged that the hospital provisions would disqualify all but the apprentices of the Irish college; that while the bill appeared to remove the old monopoly enjoyed by them and to share the county infirmary positions with graduates of other schools, in fact its qualification clauses actually extended College control to the dispensaries and fever hospitals as well. Indeed, Wakley saw in this a conspiracy of immense proportions. He feared the bill would set a precedent which would speedily be applied to both England and Scotland.

Every English and Scotch, as well as Irish practitioner, who has not paid a three years' fee to a recognized hospital, will be rendered ineligible to office in an infirmary, dispensary or other medical institution in the empire. The monopolists aim at nothing less. ${ }^{42}$

Indeed, with the best of intentions, French apparently misunderstood the medicalpolitical terrain of 1838 . While he had taken the trouble to consult many important figures in the Dublin medical community, his measure clearly favoured the licentiates of the Irish colleges, especially the surgeons, at the expense of that large body of practitioners with other credentials. Wakley's powerful attack rapidly underlined this fact.

Conducting his campaign in the Commons as well as his journal, Wakley delayed formal discussion of the bill while marshalling medical and lay opinion against it. He was increasingly successful. Petitions from medical groups and students throughout the British Isles began to pour in and were dutifully printed in the Lancet and presented to the Commons. At the meeting of the British Medical Association in March the bill was condemned to the enthusiastic applause of the audience. ${ }^{43}$ Even Denis Phelan was reported to have brought forth a petition against the bill, signed, it was said, by the whole of the Irish medical profession. ${ }^{44}$

In spite of Wakley's efforts, French persisted, reminding Wakley of "a mad knight errant of olden times asserting to the death, the chastity of a harlot." 45 But, increasingly, both the government and the Irish politicians saw it as a lost cause. Parliamentary support melted away in the face of the growing hostility of large sections of the medical community itself. By the end of June even Daniel O'Connell, once a firm supporter, expressed the hope that the bill be withdrawn for this session.

Wakley had won. There was no doubt that this was his triumph. Both in his journal and in Parliament he had led the opposition, as, indeed, he had in 1837. He had perceived the vulnerable points in the bill and had argued in the most emotional language imaginable that it served the interests not of Ireland but of a small, arrogant, and already well-endowed portion of the medical community. He thus set the various elements of the profession against each other and the laymen against all of them. Reform of the medical charities had been dealt a nearly mortal blow. Thirteen years would pass before the Medical Charities (Ireland) Act of 1851 reached the statute

\footnotetext{
42 Ibid., p. 906.

43 Ibid., p. 942.

44 Ibid.

${ }^{45}$ Ibid., ii: 87.
} 
books and only then because of the catastrophe of the Great Famine. But there was another result of Wakley's effort which was more positive, immediate, and ironic.

In both 1837 and 1838 Wakley's campaigns against the Medical Charities Bills had educated the leading members of the Irish medical profession. He had alerted them to the dangers posed by the Poor Law Commission and he had revealed the penalties of continuing the traditional quarrels and divisions. The Irish medical men proved to be excellent students. The Irish colleges of physicians and surgeons began to put out feelers designed to heal ancient wounds as early as 1837 , and the disastrous intra-professional conflict growing out of the provisions of the 1838 bill had underlined the need for greater unity. The first results of this emerging sense of community was the founding of the Dublin Medical Press in January 1839, followed in May by the establishment of the Irish Medical Association.

Previously the only medical journal in Ireland was the prestigious Dublin Journal of Medical and Chemical Science. But it was committed to a policy of printing scientific and medical articles only and would not permit editorials on medical politics. Arthur Jacob (1790-1874), one of the leading figures in the Irish College of Surgeons, had succeeded to the editorship in 1836 and had tried to change this policy but failed. Jacob, and his colleague Henry Maunsell (1806-79), were devoted to their College and saw its rigorous curriculum and monopoly of infirmary posts as a lonely bastion of excellence in the medical profession. ${ }^{46}$ As the medical charities and the College came under attack in the late 1830s, they became increasingly anxious about their inability to reply in kind to the charges levelled against them. While no direct evidence links the founding of the Dublin Medical Press with Wakley's campaign, both the timing and the circumstances make it likely that it convinced Jacob and Maunsell of the absolute need for an Irish version of the English journal, which could be used to defend the interests of the Irish College of Surgeons in the same way as Wakley had used the Lancet to attack them. The Dublin Medical Press appears to have been closely modelled on the Lancet. Both were weeklies devoted to a mixture of scientific and medical-political articles with regular and strong editorial comment. It must have been a source of some irony to Wakley that his old enemy Jacob should have paid him the ultimate compliment of founding a journal which in style, tone, and subject matter so closely resembled his own.

In the opening number Jacob defined the purposes of the new journal:

To diffuse useful knowledge, and to afford others an opportunity of doing so; to rouse the slumbering energies of the Irish practitioner; to preserve the respectability of the professional character; to inst.ll honourable principles, and foster kind feelings in the breast of the student; and to protect the institutions of the country against the attacks of those interested in their destruction. ${ }^{47}$

The Dublin Medical Press rapidly gained wide readership and a respected position in Irish medical circles. ${ }^{48}$ Articulate, abusive, and often as suspicious as Wakley at his

\footnotetext{
${ }^{46}$ Robert J. Rowlette, The Medical Press and Circular, 1839-1939. A hundred years in the life of a medical journal, London, Medical Press, 1939, pp. 3-5.

${ }^{47}$ Dublin Medical Press, 1839, $1: 1$.

${ }^{48}$ Rowlette, op. cit., note 46 above, p. 12.
} 


\section{Thomas Wakley and the Irish medical charities}

worst, Jacob and Maunsell used their journal to defend medical interests, particularly Irish medical interests, as they saw them. Although created in opposition to the editorial policy of the Lancet in the debate over the medical charities, their journal was equally committed to medical reform and the strengthening of the profession. On the broad range of issues facing the medical profession in both countries in subsequent decades, each could and did find itself frequently on the same side. In the 1860s Jacob and Maunsell retired, the Dublin Medical Press became first the Medical Press and then the Medical Press and Circular, and finally even shifted its editorial offices from Dublin to London as it evolved into a respected, mainstream, British medical journal. ${ }^{49}$

Thus Wakley's involvement in the debate over the fate of the Irish medical charities had important and, in some instances, lasting consequences both for the development of the medical charities and the Irish medical profession. The former were denied until 1851 the reorganization and secure funding they needed while the latter were taught the virtues of collegial co-operation and the value of a medical journal that could represent the views of the Irish practitioners. In addition this episode is interesting for what it reveals about the professional interaction of the regional medical communities within the United Kingdom as a whole, a perspective generally obscured by the traditional focus upon English events and personalities. Historians of the medical reform era might find that more work in Dublin and Edinburgh will provide useful contributions to our understanding of this complex and interesting period.

${ }^{49}$ Ibid., pp. 56-65, 80-8. 